\title{
At the Razor's Edge: Surgeons have Lower Stress Levels than the General Population
}

\author{
${ }^{1}$ Phillipe Abreu-Reis, ${ }^{2}$ Adonis Nasr, ${ }^{3}$ Flavio Saavedra Tomasich, ${ }^{4}$ Iwan Augusto Collaco, ${ }^{5}$ Tayron Bassani \\ ${ }^{6}$ Gustavo Moreira Clivatti, ${ }^{7}$ Alana Padilha Fontanella, ${ }^{8}$ Juliana Midori Ito, ${ }^{9}$ Marília França Madeira Manfrinato \\ ${ }^{10}$ Ivilin Hammerschmidt
}

\begin{abstract}
Objective: To evaluate the stress level in physicians of different levels of formation and to compare it between different medical specialties and the general population.
\end{abstract}

Methods: This was a cross-sectional study, using a questionnaire validated in Brazil in 2010, the Perceived Stress Scale (PSS-10).

Results: The stress level was higher among surgical doctors in comparison with clinical doctors, regardless of the stage of formation. There was a difference between the sex of the professionals, men showing lower results. None of these was statistically significant. Comparing to the American population or South Brazilian teachers, the medical preceptors presented a significant lower level of stress.

Conclusion: The medical specialty as well as gender and level of medical formation influence in the professional stress level, being elevated in fields of higher working hours and constant pressure.

Descriptors: Stress, surgery, residents, medical students.

Keywords: Panamerican Tr society, Stress level, Surgery, trauma, Quality of life.

How to cite this article: Abreu-Reis $P$, Nasr A, Tomasich FS, Collaco IA, Bassani T, Clivatti GM, Fontanella AP, Ito JM, Manfrinato MFM, Hammerschmidt I. At the Razor's Edge: Surgeons have Lower Stress Levels than the General Population. Panam J Trauma Crit Care Emerg Surg 2016;5(1):26-30.

Source of support: Nil

Conflict of interest: None

\section{RESUMEN}

Objetivo: Evaluar el nivel de estrés en los médicos de diferentes niveles de formación y compararlo entre diferentes especialidades médicas y la población en general.

Métodos: Se realizó un estudio transversal, mediante un cuestionario validado en Brasil en 2010, la Escala de Estrés Percibido (PSS-10).

\footnotetext{
${ }^{1,5}$ Resident Physician, ${ }^{2-4}$ Professor, ${ }^{6-10}$ Medical Student

1,3,5 Department of Surgery, Hospital Erasto Gaertner, Curitiba Paraná, Brazil

2,4,6-10Department of Surgery, Hospital do Trabalhador Curitiba, Paraná, Brazil

Corresponding Author: Phillipe Abreu-Reis, Resident Physician Department of Surgery, Hospital Erasto Gaertner, Curitiba, Paraná Brazil, Phone: 554199143236, e-mail: phillipeareis@gmail.com
}

Resultados: El nivel de estrés era mayor entre los médicos quirúrgicos en comparación con los médicos clínicos, independientemente de la etapa de formación. Hubo una diferencia entre el sexo de los profesionales, los hombres muestran resultados más bajos. Ninguno de estos fue estadísticamente significativa. En comparación con la población de América del Sur o profesores brasileños, los preceptores médicos presentan un nivel significativamente más bajo de estrés.

Conclusión: La especialidad médica, así como el género y el nivel de formación médica influyen en el nivel de estrés profesional, que es mayor en los campos de más horas de trabajo y presión constante.

Descriptores: Estrés, cirugía, residentes, estudiantes de medicina.

Keywords: Panamerican Tr society, Stress level, Surgery, trauma, Quality of life.

\section{INTRODUCTION}

Nine in ten people in the world are affected by stress in higher or lower levels of intensity. ${ }^{1}$ Despite the elevated prevalence, defining stress is difficult. Usually, it is described as the inability to handle daily life situations, threatening mental, physical or spiritual health..$^{2}$ Excessive stress can elicit organism alterations, impair memory, enhance anxiety, cause sleep disturbances and influence all the human systems. ${ }^{1,3}$ Health workers seem to be more susceptible to these effects then general population. ${ }^{1}$ This overwhelm occurs since the first years of medical life, still in University, when medical students were submitted to increasing levels of competitiveness, growing responsibilities as well as contact with sick people, loss and death, among others. ${ }^{1,2}$ The effort and demanded dedication increase in time, being important characteristics of medical residence, a hard and stressful time in the medical carrier formation. ${ }^{4}$ Sleep deprivation, excessive working hours and irregular work schedules are some of the factors influencing the medical stress levels. To the ones who follow academic life, like the preceptors, the time and energy spent and responsibilities demanded can also become stressors. ${ }^{5}$

With so many evidence of excessive demands and destabilizing factors to which health students and professionals are subjected, we design this study to compare the stress level between surgical and nonsurgical specialties.

Presented in the Resident Paper Competition at the Panamerican Trauma Society Congress, Santa Cruz, Bolivia in November 2015 


\section{METHODS}

A questionnaire was applied in this descriptive, crosssectional study, between March and April 2015. The questionnaire was based on the Perceived Stress Scale (PSS-10), validated in Brazil in 2010, ${ }^{6}$ to evaluate the frequency of feeling or thinking about specific stress related situations in the last 30 days.

The research was performed anonymously and voluntarily with medical preceptors and residents of surgical and non-surgical specialties as well as medical students of the fifth and sixth years of graduation (which correspond to the professionalizing cycle of formation). The results were also compared with the control population of the same age (control group A: American population and control group B: teacher population of South Brazil). ${ }^{7,8}$

Were included the subjects of 18 years of age or more, working or studying in the city of Curitiba, Brazil and surroundings. We excluded the incomplete questionnaires.

The 10 questions forms were fulfilled online, through a Microsoft Excel worksheet linked by Google. We compiled the answers in a worksheet to be analysis and interpretation.

Each question in the PSS-10 have a predefined weight, ranging from 0 to 4 . The sum of all the 10 questions scores gives the global one, ranging from 0 to 40 . The data analysis was concluded with simple percentage statistics. The continuous variables were analyzed with the Student $t$ test and the discrete ones with the $\chi^{2}$ test.

The doctors and the medical students currently on the following specialties were considered as surgical: Orthopedics, General Surgery, Coloproctology, Plastic Surgery, Obstetrics and Gynecology, Urology and Surgical Oncology. The non-surgical ones were Family and Community Medicine, Internal Medicine, Anesthesiology, Pediatrics, Neurology and Radiology. The other specialties were not represented.

\section{RESULTS}

A total of 118 subjects fulfilled the questionnaires, among which 72 medical students, 37 resident doctors and 9 preceptors. 52 were women (38 students, 11 residents and 3 preceptors) and 66 were men (34 students, 26 residents e 6 preceptors). There was no incomplete questionnaire as shown in Graph 1.

Table 1 shows that the mean age was $24.3,26.4$ and 37.3 years for the students, residents and preceptors, respectively.

There was 65 subjects from surgical specialties (5 preceptors, 25 residents and 35 students) and 53 from non-surgical specialties (4 preceptors, 12 residents e 37 students) as described by Graph 2.

Table 2 presents data from PSS-10 according to level of formation.

The PSS-10 is higher in the surgical specialties among the three levels of formation, although in none of them have the difference achieved statistical significance ( $p$ preceptors $=0.67 ; p$ residents $=0.73 ; p$ students $=0.90$ ).

In Table 3 are shown the stress scores from previews studies, which we used as control groups to comparison, according to sex and age stratification. 7,8

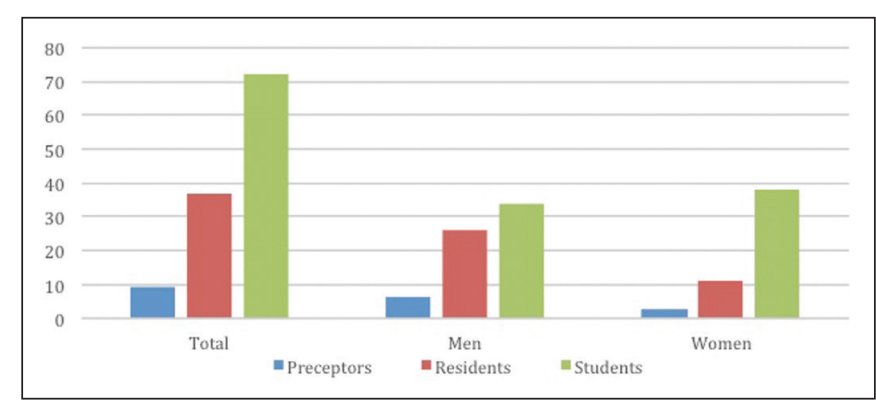

Graph 1: Responders by sex

Table 1: Mean age of subjects

\begin{tabular}{lccc}
\hline & Students & Residents & Preceptors \\
\hline Mean (years) & 24.3 & 26.4 & 37.3 \\
\hline
\end{tabular}

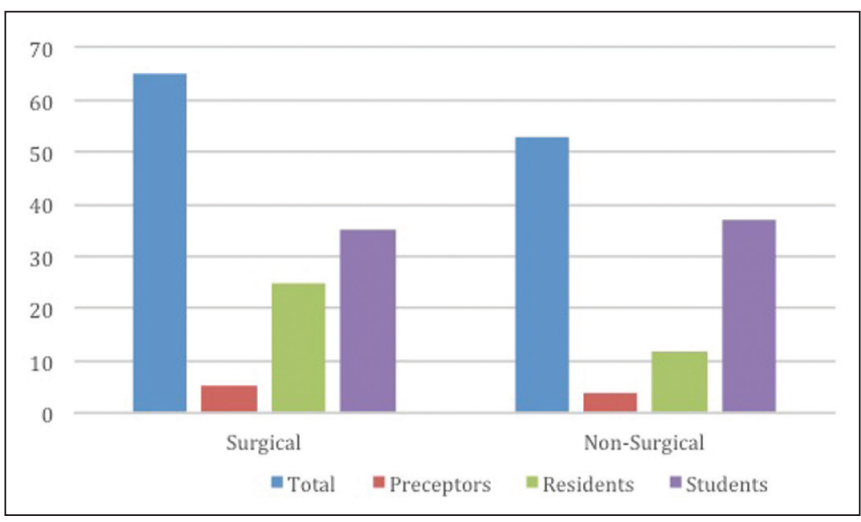

Graph 2: Responders by specialty

Table 2: Stress Scores among medical preceptors, residents and students

\begin{tabular}{llll}
\hline Preceptors & Residents & Students \\
\cline { 2 - 3 } Mean Surg NSurg Mean Surg & NSurg Mean Surg & NSurg \\
\hline
\end{tabular}

\begin{tabular}{lllllllll}
\hline Stress 12.4 & 12.8 & 12.0 & 22.0 & 22.4 & 20.9 & 19.9 & 20.4 & 19.5
\end{tabular}

Score

Table 3: Stress scores of control groups A and B, according to age and sex

\begin{tabular}{|c|c|c|c|c|c|}
\hline & & \multicolumn{2}{|c|}{$\begin{array}{l}\text { Control A: American } \\
\text { Population }\end{array}$} & \multicolumn{2}{|c|}{$\begin{array}{l}\text { Control B: South } \\
\text { Brazil Teachers }\end{array}$} \\
\hline & & $n$ & $\begin{array}{l}\text { Mean } \\
\text { (Standard } \\
\text { deviation) }\end{array}$ & $n$ & $\begin{array}{l}\text { Mean } \\
\text { (Standard } \\
\text { deviation) }\end{array}$ \\
\hline Sex & $\begin{array}{l}\text { Male } \\
\text { Female }\end{array}$ & $\begin{array}{l}926 \\
1406\end{array}$ & $\begin{array}{l}12.1(5.9) \\
13.7(6.6)\end{array}$ & $\begin{array}{l}451 \\
334\end{array}$ & $\begin{array}{l}16.3(0.6) \\
18.3(0.3)\end{array}$ \\
\hline $\begin{array}{l}\text { Age } \\
\text { (years) }\end{array}$ & $\begin{array}{l}18-29 \\
30-44 \\
45-54 \\
55-64 \\
>65\end{array}$ & $\begin{array}{l}645 \\
750 \\
285 \\
282 \\
296\end{array}$ & $\begin{array}{l}14.2(6.2) \\
13.0(6.2) \\
12.6(6.1) \\
11.9(6.9) \\
120(6.3)\end{array}$ & $\begin{array}{l}11 \\
356 \\
311 \\
88 \\
16\end{array}$ & $\begin{array}{l}21.3(2.1) \\
17.8(0.4) \\
17.2(0.4) \\
14.5(0.7) \\
15.7(1.8)\end{array}$ \\
\hline
\end{tabular}

Source: Cohen et. al, 1983 e Reis e Petroski, 2004 
The preceptors presented a lower stress score in relation to control group B (12.4 vs 17.8 points, $\mathrm{p}<0.01)$. Table 4 presents that there was no significant difference between the preceptors and the control group A stress levels (12.4 vs 13.0 points, $\mathrm{p}=0.18$ ).

On the other hand, among the residents, the stress score was higher than control group B ( 21.9 vs 21.3 points, $p<0.01$ ), but again there was no difference with the control group A (21.9 vs 14.2 points, $\mathrm{p}=0.32$ ) as follows in Table 5.

Table 6 shows that medical students had higher stress levels than the control group A (19.9 vs 14.2 points, $\mathrm{p}<0.01)$, but lower than control group B (19.9 vs 21.3 points, $\mathrm{p}<0.01$ ).

There was no difference regardless of sex when our sample was compared to the control groups. Table 7 exposes a tendency to higher stress was noted among female subjects, not statistically significant (preceptors: 14.3 vs 11.5 points, $\mathrm{p}=0.17$; residents: 26.0 vs 21.3 points, $\mathrm{p}=0.29$; students: 21.4 vs 18.3 points, $\mathrm{p}=0.95$, for female and male subjects, respectively).

The medical carrier as a whole presents physical and mental demands capable of altering the professionals quality of life and stress levels. The exhausting routine and excessive working hours are known and begin already in the University period. Free time abdication, sleep deprivation, full schedule and several hours of complimentary study add to this reality of overwhelming, specially in the finals years of graduation..$^{1}$ In this period, the responsabilities toward the patients increase, the knowledge required is bigger and the weekly working hours grow. In the medical residence, time for huge professional gain, the responsibilities and demands grow even more, making it difficult to lower the stress levels and improve the doctors quality of lives. ${ }^{4}$ To the preceptors, ethics and responsibility are essential and full dedication is demanded.

In our study, medical residents as well as students presented higher stress scores than American population

Table 4: Mean stress score among preceptors, compared to control groups A and B (age between 30-44 years)

\begin{tabular}{llll}
\hline & Preceptors & Control $A$ & $p$-value \\
\hline Mean & 12.4 & 17.8 & $<0.01$ \\
\hline & Preceptors & Control B & $p$-value \\
\hline Mean & 12.4 & 13.0 & 0.18 \\
\hline
\end{tabular}

Table 6: Mean stress score among medical students, compared to Control Groups A and B (age between 18-29 years)

\begin{tabular}{llll}
\hline & Students & Control $A$ & $p$-value \\
\hline Mean & 19.9 & 14.2 & $<0.001$ \\
\hline & Students & Control B & $p$-value \\
\hline Mean & 19.9 & 21.3 & $<0.001$ \\
\hline
\end{tabular}

(control group A), agreeing with the data from medical literature, despite not achieving statistical significance.

When compared with the control group B, residents and students have opposite behavior. Residents are more stressed then South Brazilian teachers, while students are less. The stressful routine of teachers is known and can be responsible for this difference. Inadequate behavior, indiscipline, differences regard motivation and knowledge acquisition are some factors that could justify higher stress levels in this population. ${ }^{9}$

Besides, Brazilian teachers are among the less paid in the world, situation even worse than in other Latin countries such as Chile or Mexico. Thus, our professors' lives are stressful not only in the educational field, but also financially.

What drives more attention in our study is the comparison between stress levels of medical preceptors and the control groups A and B. The formers are less stressed than the control groups, with statistical significance when compared with the American population. Several explanations can come from these results. The achievement of a stable professional carrier, without constant evaluations; better self-esteem and greater confidence on theirs skills; better financial situation; all of them could explain the results. Another aspect with influence is that preceptors' routines are very different than classical teaching. The kind of teaching, tutorial and methods are more practical and less theoretical.

In medical carriers, it is believed that surgical specialties are more stressful than clinical ones, despite the lack of studies confirming it. In our study there was a trend toward it, although no statistical significance was established.

There was also a non significant trend of more stress among women when compared to men. This could be explained by the higher level of commitment and work provided by women to prove themselves in the labor market. Also, men seem to handle daily pressures better and to present higher self-esteem than women. ${ }^{10}$

Table 5: Mean stress score among residents, compared to control groups A and B (age between 18-29 years)

\begin{tabular}{llll}
\hline & Preceptors & Control $A$ & $p$-value \\
\hline Mean & 21.9 & 14.2 & 0.32 \\
\hline & Preceptors & Control B & $p$-value \\
\hline Mean & 21.9 & 21.3 & $<0.001$ \\
\hline
\end{tabular}

Table 7: Mean stress score in men and women.

\begin{tabular}{llll}
\hline & Women & Men & $p$-value \\
\hline Preceptors & 14.3 & 11.5 & 0.17 \\
Residents & 26.0 & 21.3 & 0.29 \\
Students & 21.4 & 18.3 & 0.95 \\
\hline
\end{tabular}




\section{CONCLUSION}

It is known that the medical carrier demands time, dedication and perseverance. Still, it is possible to find differences inside this huge working field. Our study shows that specialty choose can affect stress levels of medical professionals. The same way, the educational and the professional periods have different impact in the mental well-being of the doctors.

\section{REFERENCES}

1. Meyer C, Guimarães ACA, Machado Z, Parcias SR. Qualidade de Vida e Estresse Ocupacional em Estudantes de Medicina. Revista Brasileira de Educação Médica. 2012;36(4): 489-498.

2. Vrushali SB, Jayashree VG. Study of stress, self-esteem and depression in medical students and effect of music on perceived stress. Ind J Physiol Pharmacol 2014;58(3): 296-299.

3. Abdulghani HM, et al. Prevalence of stress in junior doctors during their internship training: a cross-sectional study of three Saudi medical colleges' hospitals. Neuropsychiatr Dis Treat 2014 Dec;10:1879-1886.

4. Alosaimi FD, Kazim SN, Amufleh AS, Aladwani BS, Alsubaie AS. Prevalence of stress and its determinants among residents in Saudi Arabia. Saudi Med J 2015;36(5):605-612.

5. Hautala KT, Saylor CR, O\'Leary-Kelley C. Nurses' Perceptions of Stress and Support in the Preceptor Role. J Nurses Staff Dev 2007;23(2):64-70.

6. Reis RS, Hino AAF, Rodiguez-Añes CR. Perceived Stress Scale: reliability and Validity Study in Brazil. J Health Psychol 2010;15(1):107-114.

7. Cohen S, Kamarck T, Mermelstein R. A Global Measure of Perceived Stress. J Health Soc Behav 1983;24():385-396.

8. Petroski EC. Qualidade de vida no trabalho e suas relações com estresse, nível de atividade física e risco coronariano de professores universitários. 2005

9. Silveira KA, Enumo SRF, Paula KMP, Batista EP. Estresse e enfrentamento em professores: Uma análise da literatura. Educação em Revista 2014;30(Outubro-Dezembro):15-36.

10. Verdonk P, Räntzsch V, Vries R, Houkes. Show what you know and deal with stress yourself: a qualitative interview study of medical interns' perceptions of stress and gender. BMC Med Educ 2014;96(14). 


\section{At the Razor's Edge: Surgeons have Lower Stress Levels than the General Population}

I will like to congratulate the authors for analyzing such an important aspect of the medical profession. Identifying the physical and mental stresses of the medical providers is essential to create new ways in improving the working environment of our profession.

However, I have some questions and specific recommendations for the authors: (1) Develop a more detailed analysis about the differences between the genders, including between surgical and non-surgical specialties, on their degree of stress. (2) Expand on the differences between cohort groups A and B. (3) Further discussion about the specific findings encountered among the preceptors. (4) Further discussion about the high level of stress found among the teachers and the social, political and economic factors producing the difference between Latin American countries. (5) Is there is an explanation about the higher number of women among the students as compared to the resident's group?

Manuel Lorenzo
Professor of Surgery
Methodist Dallas Medical Center
Dallas, Texas

\section{Al filo de la navaja: Los cirujanos tienen niveles bajos de estrés comparado a la población general}

Me gustaría felicitar a los autores por el análisis de un aspecto tan importante de la profesión médica. La identificación del estrés físico y mental de los proveedores de servicios médicos es esencial para crear nuevas formas de trabajo en la mejora del medio ambiente de nuestra profesión.

Sin embargo, tengo algunas preguntas y recomendaciones específicas para los autores: (1) Desarrollar un análisis más detallado sobre las diferencias entre géneros, incluyendo especialidades quirúrgicas y no quirúrgicas, en su grado de estrés. (2) Ampliar en las diferencias entre el grupo cohorte A y B. (3) Continuación de discusiones sobre los resultados específicos encontrados entre los preceptores. (4) Además discusión sobre el alto nivel de estrés que se encuentra entre los maestros y los factores sociales, políticos y económicos que produce la diferencia entre los países de América Latina. (5) ¿Hay una explicación sobre el porqué de un mayor número de mujeres entre los estudiantes en comparación con el grupo de residentes?

Manuel Lorenzo Profesor de Cirugía Methodist Dallas Medical Center Dallas, Texas, USA 